\title{
EVALUASI PROGRAM PENDIDIKAN KARAKTER KEJUJURAN SISWA SD MUHAMMADIYAH SAPEN YOGYAKARTA
}

\author{
Linda Widiyanti \\ Program Pasca Sarjana \\ Universitas Muhammadiyah Yogyakarta \\ E-mail: dantokrissuwarno1964@gmail.com
}

\begin{abstract}
Abstrak
Penelitian ini bertujuan untuk mengungkap dan menganalisis tingkat pendidikan karakter dalam ranah afektif nilai kejujuran, dan mengetahui strategi dalam meningkatkan kejujuran siswa SD Muhammadiyah Sapen Yogyakarta. Penelitian ini menggunakan metode campuran (Mixed Method). Subjek penelitian ini adalah kepala sekolah, guru kelas, dan siswa.Pengumpulan data diambil melalui angket,observasi, wawancara, dan dokumentasi. Data dianalisis dengan menggunakan langkah-langkah reduksi data, display data, dan penarikan kesimpulan. Hasil penelitian menunjukkan bahwa tingkat pendidikan karakter kejujuran siswa SD Muhammadiyah sapen adalah sebagai berikut: dalam kategori sangat baik $(>97,5)$ sebanyak 2 siswa, kategori baik $(75$ sd 97,5) sebanyak 27 siswa, kategori kurang (52,5 sd 75) sebanyak 2 siswa, sedangkan tidak ada siswa yang masuk dalam kategori sangat kurang $(<52,5)$. Maka dapat disimpulkan bahwa tingkat kejujuran siswa SD Muhammadiyah Sapen termasuk dalam kategori baik.
\end{abstract}

Kata Kunci: evaluasi,nilai-nilai karakter, nilai kejujuran

\begin{abstract}
This study aims to 1) find out the improvement of laboratory management competencies through structured training with techniques to visit each other for the head of the laboratory in Teras Sub-district Middle School in the second semester of the 2016/2017 school year. structured training with techniques of visiting each other in the second semester of the 2016/2017 school year, 3) knowing changes in behavior of the head of the laboratory in Teras District Middle School in managing the laboratory after conducting structured training with visiting techniques in the second semester of the 2016/2017 school year The method of this research is the method of school action research by giving action in 2 cycles. The research subjects were the head of the laboratory in Teras Sub-district Middle School with a sample of 12 laboratory heads from 3 public and private junior high schools. The results of this school action research show that there are: 1) improvement of the training process to improve the competence of the head of the laboratory; 2) there is an increase in performance of 42.50 (117.2\%) from the average performance value of 36.25 to 78.75 and an increase in laboratory management by 43.50 (128.8\%) from the average value of 33.75 to 77.50 ; and (3) changes in the positive behavior of the head of the laboratory from sufficient categories are quite high.
\end{abstract}

Keywords: structured training, assessment of laboratory head performance, laboratory management supervision, and laboratory visits.

\section{Info Artikel}

Diterima Maret 2019, disetujui April 2019, diterbitkan Juni 2019 


\section{PENDAHULUAN}

Pendidikan karakter hadir sebagai solusi problem moralitas dan karakter itu.Meski bukan sebagai sesuatu yang baru, pendidikan karakter cukup menjadi semacam "greget" bagi dunia pendidikan pada khususnya untuk membenahi moralitas enerasi muda. Berbagai macam alternatif guna mengatasi krisis karakter, memang sudah dilakukan dan penerapan hukum yang lebih kuat. Adapun altenatif lain yang banyak dikemukakan untuk mengatasi, sehingga dapat mengurangi masalah budaya dan karakter bangsa yang dibicarakan itu adalah melalui pendidikan karakter.

Nilai karakter kejujuran harus ditanamkan pada anak sejak dini dikarenakan nilai kejujuran salah satu nilai kunci dalam kehidupan. Pendidikan kejujuran dapat diintegrasikan kedalam kehidupan keluarga, masyarakat maupun sekolah. Apabila pendidikan kejujuran dapat dilaksanakan secara efektif maka kita telah membangun landasan yang kokoh berdirinya bangsa. Dewasa ini bangsa kita sedang mengalami krisis kejujuran sehingga berdampak pada melandanya perilaku korupsi di manamana, bahkan telah dinyatakan bahwa korupsi telah membudaya.

Pada tahun 2013,SD Muhammadiyah Sapen meraih Juara I Practice Bidang Pendidikan Karakter Sekolah Dasar. SD Muhammadiyah Sapen yang bervisi :"Terbentuk Pribadi Muslim yang Unggul, Berakhlak Mulia, Berbudaya dan Berwawasan Global'.Dan salah satu Misinya yaitu mengembangkan pembelajaran berbasis IT dan kemampuan berbahasa asing, mengembangkan budaya disiplin dan etoskerja yang tinggi, meningkatkan manajemen partisipatif yang melibatkan siswa, guru, orang tua dan stakeholder sekolah. Salah satu karakter ini adalah kurangnya kejujuran. Kejujuran akhir-akhir ini merupakan sesuatu yang asing. Hal ini membuat hanya dimiliki oleh segelintir orang saja. Sehingga muncullah istilah "jujur ajur".

\section{METODE PENELITIAN}

\section{Pendekatan Penelitian}

Penelitian ini menggunakan metode campuran (Mixed Method),yaitu metode yang memadukan pendekatan kualitatif dan kuantitatif dalam hal metodologi (seperti dalam tahap pengumpulan data), dan kajian model campuran memadukan dua pendekatan dalam semua tahapan proses penelitian. 


\section{Model Evaluasi}

Model Evaluasi yang digunakan adalah model Stake.Model ini memberikan metode yang sistematis untuk mengevaluasi pendidikan karakter di SD Muhammadiyah Sapen Yogyakarta.Ditinjau dari pendekatannya model stake dianggap efisien, karena evaluasi diarahkan untuk pengambilan keputusan dan prosesnya terfokus pada aspek tertentu yang terkait dengan program yang sedang berjalan.

Penentuan keberhasilan program memerlukan suatu kriteria penilaian, kriteria penilaian meliputi:

1. Aspek Antecendent

a. Tersedia tenaga pengajar yang memiliki keahlihan sebagai guru dalam menunjang tugasnya sebagai pengajar.

b. Tersedia sarana dan prasarana yang dibutuhkan dalam proses pembelajaran.

c. Siswa yang mempunyai motivasi yang tinggi untuk belajar

2. Aspek Transaction

a. Pelaksanaan pembelajaran yang dilaksanakan oleh guru berjalan dengan baik.

b. Tingginya partisipasi siswa dalam pembelajaran

c. Terjadinya hubungan antar pribadi yang baik dalam pembelajaran

3. Aspek Outcome

a. Siswa mampu mencapai prestasi akademik yang sesuai dengan target pembelajaran

b. Siswa mempunyai akhlak yang baik

\section{Sumber Data}

Sumber data dalam peneltian ini adalah 2 kepala sekolah, 4 guru, dan 31 siswa. Sumber data tersebut ditentukan dengan menggunakan teknik purposesive, yaitu penentuan sumber data dengan menggunakan kriteria tertentu yang disesuaikan dengan fokus penelitian. Kroteria pemilihan sumber data dalam penelitian ini bahwa kepala sekolah sebagai pihak yang berwenang menentukan kebijakan pelaksanaan pendidikan karakter, guru sebagai pihak yang bersinggungan langsung dengan siswa, termasuk dalam hal pelaksanaan pendidikan karakter, siswa adalah subjek didik yang akan dibangun karakternya melalui pendidikan karakter. Teknik ini digunakan dengan alasan 
agar yang menjadi sumber data mempunyai bahan informasi yang lengkap, terarah dan representatif.

\section{Metode dan Instrumen Pengumpulan Data}

\section{Angket atau koesioner (questionnaires)}

Metode ini digunakan untuk memperoleh data yang berkaitan dengan jujur dan dengan menggunakan skala likert yang diberikan kepada peserta didik kelas $\mathrm{V}$ tahun ajaran 2017/2018. Dengan menggunakan lima katagori pilihan yaitu selalu (SL), sering (SR), kadang-kadang (KDG) dan tidak pernah (TP)

\section{Dokumentasi}

Dokumentasi/pencatatan arsip digunakanuntuk menghimpun data mengenai monografi SD Muhammadiyah Sapen Yogyakarta sebagai lokasi penelitian.

\section{Observasi (Observation)}

Observasi juga digunakan untuk melihat secara langsung bentuk penanaman karakter kejujuran dan hambatannya pada siswa di SD Muhammadiyah Sapen Yogyakarta.

\section{Wawancara (Interview)}

Wawancara digunakan sebagai teknik pengumpulan data apabila peneliti ingin melakukan studi pendahuluan untuk menemukan permasalahan yang harus diteliti. Wawancara dalam penelitian ini digunakan untuk menghimpun data sebanyakbanyaknya dari narasumber mengenai penanaman karakter kejujuran pada siswa SD Muhammadiyah Sapen Yogyakarta. Peneliti mendengarkan cerita yang diperoleh dari informan dan bisa juga mengajukan berbagai pertanyaan yang lebih terarah untuk menjawab rumusan masalah penelitian.

\section{HASIL PENELITIAN DAN PEMBAHASAN}

\section{Tingkat Kejujuran}

Hasil deskriptif data penelitian kejujuran menyatakan bahwa dari 31 siswa yang mengisi angket kejujuran memperoleh Mean (M) sebesar 84,87, Median (Me) sebesar 
84,00, Mode (Mo) sebesar 81,00, Standar Deviasi sebesar 7,40. Supaya mudah dalam membaca hasil penelitian ini, berikut akan disajikan tabel distribusi frekuensi kejujuran;

Tabel 1.

Distribusi Frekuensi Hasil Tes Kejujuran

\begin{tabular}{|c|c|c|c|}
\hline No & Interval Kelas & Frekuensi & Persentase (\%) \\
\hline 1. & $102-109$ & 1 & 3,23 \\
\hline 2. & $94-101$ & 2 & 6,44 \\
\hline 3. & $86-93$ & 10 & 32,27 \\
\hline 4. & $78-85$ & 15 & 48,39 \\
\hline 5. & $70-77$ & 3 & 9,67 \\
\hline \multicolumn{2}{|c|}{ TOTAL } & 31 & 100 \\
\hline
\end{tabular}

Berdasarkan tabel diatas tentang distribusi frekuensi kejujuran dapat digambarkan dengan histogram sebagai berikut;

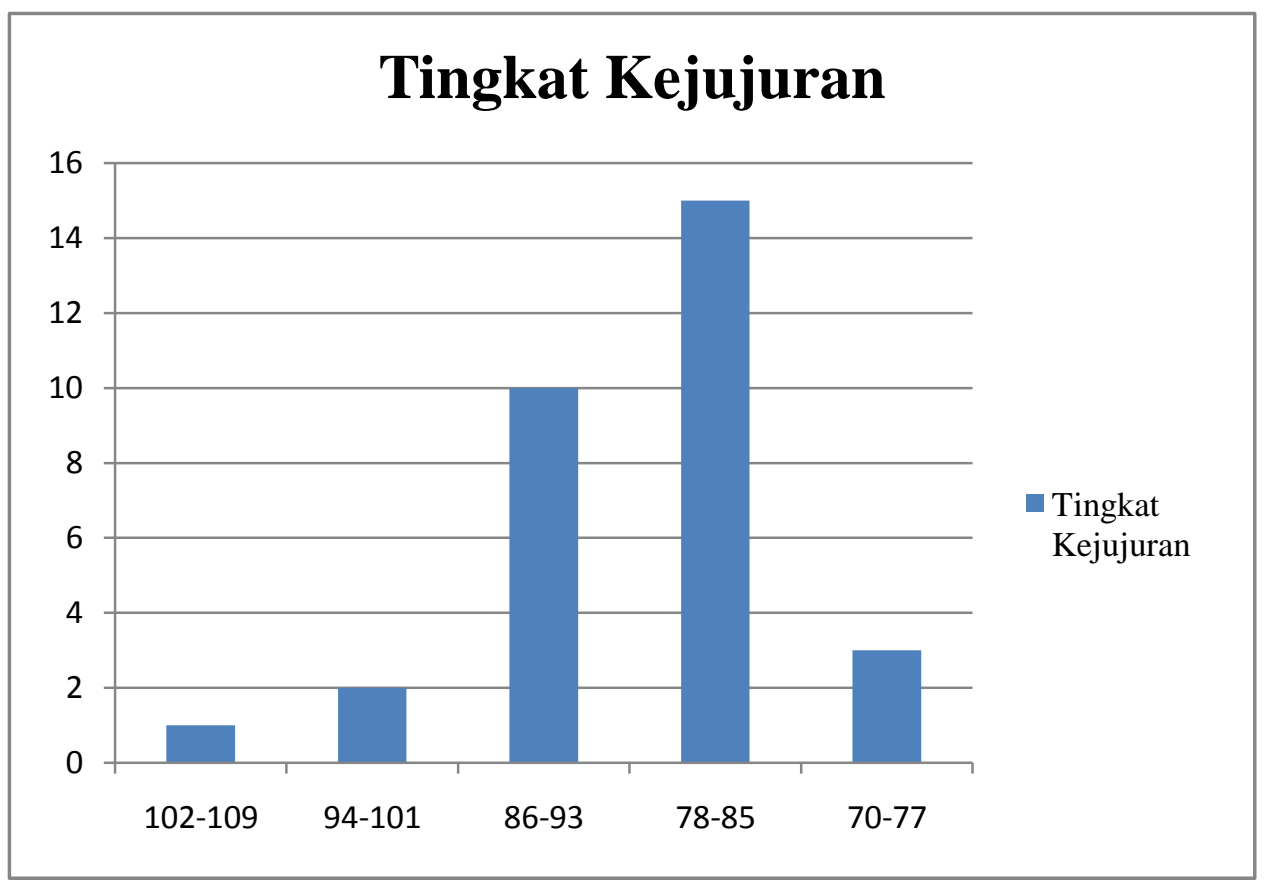

Gambar1. Distribusi Frekuensi Kejujuran

Untuk mengidentifikasi kategori kejujuran ditetapkan skor ideal. Dari skor ideal tersebut dikategorikan dalam 4 kategori yaitu: Sangat Baik, Baik, Kurang, dan Sangat Kurang. Berikut tabel kategori kejujuran yang akan disajikan dalam tabel di bawah ini; 
Tabel 2.

Distribusi Frekuensi Kategori Kejujuran

\begin{tabular}{|c|c|l|c|c|}
\hline \multirow{2}{*}{ No } & \multirow{2}{*}{ Skor } & \multirow{2}{*}{ Kategori } & \multicolumn{2}{|c|}{ Frekuensi } \\
\cline { 4 - 5 } & & & Absolute & Relative (\%) \\
\hline 1. & $>97,5$ & Sangat Baik & 2 & 6,44 \\
\hline 2. & $75 \mathrm{sd} 97,5$ & Baik & 27 & 87,12 \\
\hline 3. & $52,5 \mathrm{sd} 75$ & Kurang & 2 & 6,44 \\
\hline 4. & $<52,5$ & Sangat Kurang & 0 & 0 \\
\hline
\end{tabular}

Berdasarkan tabel di atas dapat diketahui bahwa, kategori kejujuran siswa SD Muhammadiyah Sapen yang masuk dalam kategori sangat baik (>97,5) sebanyak 2 siswa, kategori baik (75 sd 97,5) sebanyak 27 siswa, kategori kurang (52,5 sd 75) sebanyak 2 siswa, sedangkan tidak ada siswa yang masuk dalam kategori sangat kurang $(<52,5)$. Maka dapat disimpulkan bahwa tingkat kejujuran siswa SD Muhammadiyah Sapen termasuk dalam kategori baik.

\section{Strategi Pembentukan Karakter kejujuran siswa SD Muhammadiyah Sapen Yogyakarta}

\section{Pendidikan Karakter Kejujuran Melalui Budaya Sekolah}

Budaya sekolah yang berkembang diSD Muhammadiyah sapen mencerminkan budaya positif yang bermuatan nilai karater kejujuran didalamnya.Hal ini Lickona menjelaskan bahwa sekolah dapat merancang budaya moral yang positif dengan melakukan 8 elemen yaitu (1) kepemimpinan kepala sekolah, (2) mempromosikan dan menegakkan nilai-nilai disiplin diseluruh lingkungan sekoalah, (3) menegakkan rasa kebersamaan, (4) melibatkan siswa untuk menciptakan suasana yang demokratis, (5) menciptakan suasana moral, (6)memposisikan moral sebagai sesuatu yang penting disekolah.

Budaya sekolah yang berkembang di SD Muhammadiyah Sapen dilaksanakan melalui berbagai aktivitas baik kegiatan rutin, kegiatan spontan, pengkondisian, maupun keteladanan.Dikemas pelaksanaan budaya sekolah dalam berbagai kegiatan tersebut penting dilakukan dalam mendukung keberhasilan pendidikan karakter disekolah dasar. Hal ini senada dengan pendapat Nucci \& Narvaez (2008:175) yang menjelaskan bahwa 
siswa dapat mengembangkan konsepsi mereka tentang cara menjadi orang yang baik malalui beberapa aktivitas yaitu penegakkan aturan sekolah, pembiasaan yang terjadi di kelas, prosedur yang harus dilakukan sehari-hari dikelas, dan konsekuensi-konsekuensi yang harus diterima atas tindakan yang dilakukan.

\section{Pendidikan Karakter Terintegrasi Dalam Pembelajaran}

Integrasi pendidikan karakter melalui pembelajaran dalam penelitian ini sejalan dengan temuan penelitian Kurniawan (2013) bahwa : (1) nilai-nilai karakter yang diintegrasikan kedalam mata pelajaran PKn SD yaitu peduli sosial, jujur, cerdas cinta tanah air, demokratis, disiplin, kerja keras, menghargai prestasi, peduli lingkungan, rasa ingin tau,semagat kebangsaan, tanggung jawab, toleransi; (2) Pengintegrasian nilai karakter kedalam perangkat pembelajaran PKn SD dilakukan dengan cara memahami substansi SK dan KD. Dari temuan penelitian tersebut sama ketika dibandingkan dengan data hasil penelitian ini dimana dalam pembelajaran banyak nilai karakter yang ditumbuhkan. Terkait dengan nilai karakter yang dikembangkan mengacu pada tuntutan kompetensi dasar aspek sikap dalam kurikulum 2013 yang dimuat dalam mata pelajaran PKn sesuai dengan pendapat yang disampaikan oelh Athur J. (2005: 239) bahwa pendidikan karakter merupakan pendekatan yang spesifik dalam pendidikan nilai dan moral yang secara konsisten dikaitkan dengan Pendidikan Kewarganegaraan (PKn) disekolah dasar merupakan salah satu mata pelajaran wajib yang harus disampaikan dalam kurikulum.

Pendidikan karakter melalui integrasi pembelajaran disekolah dasar sangat penting. Dalam proses belajar mengajar posisi guru adalah sebagai pihakk yang memiliki kewenangan untuk mengelola proses belajar mengajar sejak perencanaan, pelaksanaan hingga evaluasi. Peran guru disini dianggap penting mengingat pendapat yang disampaikan oleh Jennings \& DiPrete (2010: 135) yang menjelaskan bahwa guru memiiki peran didalam kelas untuk pengaruh kemampuan sosial dan perilaku siswa dibandingkan pengaruhnya dalam penegembangan akademik siswa, terutama untuk usia siswa SD kelas awal.

Hal tersebut tentunya berkaitan dengan peran guru dikelas yang di idolakan oleh siswa sebagai orang yang lebih banyak mendapat perhatian siswa,termasuk dalam perilakunya. Berawal dari pengamatan terhadap perilaku guru, lambat laun siswa akan 
meniru apa yang dilakukan guru. Hal ini tidal terlepas dari keteladanan yang diberikan oleh guru. Sanderse, W.(2013) yang menjelaskan bahwa guru merupakan salah satu pihak yang dijadikan model bagi siswa dalam pendidikan karakter, disamping orang tua dan orang-orang yang punya relasi dengan siswa.

Masuknya muatan pendidikan karakter dalam pembelajaran juga sesuai dengan pendapat Glanzer dan Milson (2006: 534) mengtip apa yang ada dalam Character Education Partnership (CEP) dalam Character Education Quality (CEP, 2005a,2005b) yang enjelaskan pada salah satu yang harus dilakukan dalam pendidikan karakter yang komperhensif adalah memasukkan kurikulum akademik yang bermakna dan menantang yang menghormati semua peserta didik, mengembangkan karakter mereka dan membantu mereka untuk sukses.Proses integrasi pendidikan karakter dalam pembelajaran ditujukan dalam rangka untuk mengembangkan karakter siswa. Maka dari itu dalam kurikulum sekolah ditekankan muatan nilai karakternya.

\section{Pendidikan Karakter Kejujuran Melalui Ekstrakurikuler}

Pelaksanaan pendidikan karakter di SD Muhammadiyah Sapen dilakukan juga melalui kegiatan ekstrakurikuler yang diadakan di sekolah. Kegiatan ekstrakurikuler di SD Muhammadiyah Sapen sangat beragam.hasil wawancara dengan koordinator Kegiatan Ekstrakurikuler bahwa "kegiatan ekstra dikelompokkan menjadi 4 (empat) yaitu kelompok agama, olahraga, seni, dan bahasa". Dari keempat kelompok tersebut masih memiliki yang lebih banyak. Pengelompokan bidang ekstrakurikuler yang demikian sesuai dengan pendapat Daniel (2011: 638) yang mengelompokkan macammacam kegiatan ekstrakurikuler kedalam kaderisasi, olahraga, seni, dan kreativitas.

\section{KESIMPULAN}

Berdasarkan hasil penelitian, analisis data dan pembahasan pada hasil penelitian ini bahwa tingkat kejujuran siswa SD Muhammadiyah Sapen termasuk dalam kategori baik.Pelaksanaan pendidikan karakter kejujuran di SD Muhammadiyah Sapen dilakukan melakukan melalui 1)integrasi dalam pembelajaran,2) Pendidikan karakter melalui budaya sekolah 3) Pendidikan karakter dilakukan melalui kegiatan ekstrakurikuler. Berdasarkan kesimpulan dan dengan memperhatikan keterbatasan penelitian ini, maka saran yang dapat disampaikan peneliti adalah sekolah sebaiknya dapat mengembangkan 
enam indikator nilai kejujuran disekolah,antara lain membuat dan mengerjakan tugas secara benar, tidak menyontek atau memberi contekan, melaporkan kegiatan sekolah secara transparan, melakukan sistem perekrutan siswa secara benar dan jujur, dan melakukan sistem penilaian yang akauntabel dan tidak melakukan manipulasi dalam pengembangan kurikulum di sekolah.

\section{DAFTAR PUSTAKA}

Agus Wibowo, Pendidikan Karakter ; Strategi Membangun Karakter Bangsa Berperadaban, ( Yogyakarta Pustaka Pelajar,2012, ), hlm.25.

Sugiyono. (2013). Metode Penelitian KOMBINASI (Mixed Methods). Bandung:ALFABETA, cv.

Nucci, L. P., 7 Narvaez, D. (2008). Handbook of moral and character education. New york: Routledge.

Athur, J. (2005). The Re-Emergence Of Character Education In British Education Policy. British Journal of Educational Studies. 53 (3), 239-254.

Jenngis, J. L \& Diprete, T.A.(2010). Teacher effects on social and behavioral skills in early elementary school. Sosiology of Education, 83 (2), 135-159.

Sanderse, W. (2013). The meaning of role modelling in moral and character education. Journal of Moral Education, 42,(1), 28-24.

Glanzer, P. L,\& Milson, A. J.(2006). Legislatimg the good : a survey and evaluation of character education laws in the United States. Educational Policy, 20(3), 525550 .

Danial, E. (2011). Sinergi Ekstra Kurikuler untuk Character Building di Sekolah.Dalam Budimansyah, D., dan Komalasari, K. (editor). Pendidikan Karakter: Nilai inti bagi upaya pembinaan kepribadian bangsa. Bandung: Widya Aksara Pers. 